\title{
UNVEILING THE ACTIONS OF NURSES IN PRIMARY HEALTH CARE GROUPS
}

\author{
Priscila Rosa Maceno ${ }^{1}$, Ivonete Teresinha Schulter Buss Heidemann ${ }^{2}$
}

\begin{abstract}
${ }^{1}$ M.Sc. in Nursing. Graduate Program in Nursing (PEN) of Universidade Federal de Santa Catarina (UFSC). Florianopolis, Santa Catarina, Brazil. E-mail: priprimaceno@hotmail.com

${ }^{2}$ Ph.D. in Public Health Nursing. Professor, Nursing Department, PEN/UFSC. Florianópolis, Santa Catarina. E-mail: ivonete. heidemann@ufsc.br
\end{abstract}

\begin{abstract}
The aim was to know the health promotion actions developed by nurses in the collective services of primary health care in Florianópolis, Santa Catarina, Brazil. Exploratory, descriptive, qualitative study. The participants were ten nurses working in primary health care groups in the year 2012. Semi-structured interviews were used for data collection and the data were analyzed through thematic analysis and discussed in the light of health promotion. Five categories emerged: Nursing education and development of the health promotion group; Duties of the nurse in the group; Methodology of the group; Issue included in the groups and Results of the group. A total of 1,363 collective services were identified, with 247 being related to health education activities. The focus of activities in the groups was based on chronic diseases, did not follow specific methodology and the themes were constructed according to the pathophysiology of diseases or professional specificity. The importance is highlighted of health promotion through educational practices in the collective services, as a form of care and encouragement for the autonomy of the individual/community.
\end{abstract}

DESCRIPTORS: Health promotion. Health education. Nursing, team. Primary health care.

\section{DESVELANDO AS AÇÕES DOS ENFERMEIROS NOS GRUPOS DA ATENÇÃO PRIMÁRIA À SAÚDE}

RESUMO: Conhecer as ações de promoção da saúde desenvolvidas por enfermeiros nos atendimentos coletivos da atenção primária à saúde no município de Florianópolis, Santa Catarina, Brasil. Estudo exploratório, descritivo, de natureza qualitativa. Participaram dez enfermeiros que trabalhavam nos grupos de atenção primária à saúde, no ano 2012. Para coleta de dados, utilizou-se a entrevista semiestruturada, e os dados foram analisados com a técnica de análise temática e discutidos à luz da promoção da saúde. Emergiram cinco categorias: Formação do enfermeiro e desenvolvimento do grupo de promoção da saúde; Atribuições do enfermeiro no grupo; Metodologia do grupo; Temáticas incluídas nos grupos e Resultados do grupo. Identificou-se 1.363 atendimentos coletivos, sendo que 247 estão relacionados às atividades de educação em saúde. $\mathrm{O}$ foco das atividades nos grupos baseia-se nas doenças crônicas, não seguindo metodologia específica e as temáticas são construídas de acordo com a fisiopatologia das doenças ou especificidade profissional. Destaca-se a relevância da promoção da saúde por meio das práticas educativas nas atividades de atendimentos coletivos, como forma de cuidado e estímulo à autonomia do indivíduo/comunidade.

DESCRITORES: Promoção da saúde. Educação em saúde. Equipe de enfermagem. Atenção primária à saúde.

\section{REVELANDO EL ACCIONES DE ENFERMERAS EN GRUPOS DE ATENCIÓN PRIMARIA DE SALUD}

RESUMEN: Conocer las acciones de promoción de salud desarrollados por enfermeras en la atención colectiva de la atención primaria de salud en Florianópolis-Santa Catarina. Estudio cualitativo exploratorio descriptivo. Un total de diez enfermeras que trabajan en los grupos de salud primaria, en el año 2012. Para la recolección de datos, se utilizó una entrevista semi estructurada, y los datos fueron evaluados a partir del técnica análisis temático, discutido en el contexto de la promoción de la salud. Cinco categorías surgieron: la formación; asignaciones; metodología; temática y resultados. Se identificó 1.363 llamadas colectivas, y 247 están relacionados con actividades de educación sanitaria. El objetivo de las actividades en grupos en función de la enfermedad crónica, no se sigue una metodología específica y los temas se construyen de acuerdo a la fisiopatología de las enfermedades o especificidad profesional. Hacemos hincapié en la importancia de la promoción de la salud a través de prácticas educativas en las actividades de atención colectiva como una manera de cuidar y fomentar la autonomía del individuo/comunidad.

DESCRIPTORES: Promoción de la salud. Educación para la salud sanitaria. Atenció primaria de salud. 


\section{INTRODUCTION}

Health promotion is seen as one of the main strategies by which individuals are able to have greater control over their own health, ${ }^{1}$ recognizing their limits and improvement their quality of life. This concept, adopted by the participants of the First International Conference on Health Promotion in 1986, resulted in the Ottawa Charter document, establishing the following as promotion strategies: healthy public policies; creating healthy environments; strengthening community action; developing personal skills; and reorienting the health system. ${ }^{1}$

Working with health education is one of the modes of action of these strategies, especially when it addresses the development of personal skills, considering that primary health care ( $\mathrm{PHC}$ ) groups aim to encourage self-care and include the individual and family in their health context.

In the PHC, educational activities carried out in groups by nurses are fundamental to the training of the individual in self-care related to health. The interaction and exchange of experiences among people with similar needs enable the adoption of healthy behaviors and habits. In Brazil, health promotion, as one of the strategies of the social production of health, considers the health services to be prime locations for conducting health promotion activities, such as encouraging physical activity, a healthy diet and the control of tobacco and alcohol use, with particular attention on the aging process, among others. Therefore, health education becomes a main duty of the professionals who compose the team..$^{2-3}$

The working in groups, mainly performed by nurse in PHC, is an alternative to the care and collective practices and these spaces foster the thinking and acting of all involved, not only in the personal aspect, but also in the professional, through the valorization of scientific knowledge, creatively intervening in the health of every person. Liberating education should inspire group practices in health, allowing the users to actively seek their health. ${ }^{3-5}$

This study had the guiding question: which health promotion actions are developed in groups by PHC nurses in Florianópolis? The aim was to know the health promotion actions developed by nurses in the PHC collective services in Florianópolis, Santa Catarina, Brazil.

\section{METHOD}

This was an exploratory, descriptive and qualitative study. The study sites were family health units of Florianopolis. The PHC organizational system consists of 49 health units, divided into five districts: Continent, Center, East, North and South. Currently, the City Network has 100 Estratégia Saúde da Família (Family Health Strategy - FHS) teams: with 14 in the Center District; 27 in the Continent District; 17 in the East District; 20 in the North District; and 22 in the South District.

To achieve the aims of the study, initially, data collection was carried out in the Florianópolis $\mathrm{Mu}-$ nicipal Health Department, through the Relatório de Acompanhamento e Atendimentos Coletivos (Monitoring and Collective Services Report - RAAC), implemented in 1999. This step consisted of the summary of these reports in each health unit, through a form used as an information system that recorded the activities of groups carried out in the municipality. This had the advantage of eliminating the filling of reports of data records standardized by the Ministry of Health $(\mathrm{MOH})$, which collect the production data for the Sistema de Informação Ambulatorial do Sistema Único de Saúde (Outpatient Information System of the Brazilian National Health System - SIA-SUS). To ensure that each region had a specified chance of selection, there was a division of the groups geographically distributed in each District: North, South, East, Center and Continent.

The selection of participants for the study was conducted in two stages. At first, all the groups described in the RAAC of the five PHC Health Districts were identified. In the second stage, ten groups were selected, two in each district. After the draw of the groups, ten nurses working in them were selected.

For distribution of an equal sample, two nurses were intentionally chosen from each District according to the following criteria: the nurses of the study, who participated in group activities and were present in the unit. Those who did not perform educational activities, those who were on vacation, and those doing home visits were excluded.

From this, semi-structured interviews were carried out with the selected participants, as shown in Table 1, aiming to understand the perception of these professionals regarding training, duties, methodology, themes, subjects and results of what was addressed in the PHC group activities. The interviews took place from March to August 2012, with an approximate time of between 12 and 40 minutes, in a quiet, private space at the health unit, with the date and time previously scheduled. The participants were informed about the importance of the study and the consent form was signed. For data registration, audio recorders and diary notes were used. In possession of the data, the 
proposed thematic analysis was performed in three stages: pre-analysis, exploration of the material and processing of the results obtained with their interpretation. ${ }^{6}$

Table 1 - Characterization of the nurses per group randomly selected from each Health District (HD). Florianópolis, SC, Brazil, 2012

\begin{tabular}{|c|c|c|c|c|c|c|c|c|}
\hline Nurse & Contract & Specialization & Working time & Gender & Group & $\begin{array}{c}\text { Health } \\
\text { unit }\end{array}$ & $\begin{array}{c}\text { Draw } \\
\text { number }\end{array}$ & HD \\
\hline 1 & Private & Intensive Care Unit & 2 years & F & Diabetic & A & 276 & Center \\
\hline 2 & Public & $\begin{array}{c}\text { Public Health Man- } \\
\text { agement }\end{array}$ & $\begin{array}{c}1 \text { year and } 6 \\
\text { months }\end{array}$ & F & Time to eat & B & North \\
\hline 3 & Private & Public Health & 1 year & F & Time to eat & C & 17 & South \\
\hline 4 & Public & Family Health & 10 years & F & Time to eat & D & E & South \\
\hline 5 & Public & $\begin{array}{c}\text { Master's in Family } \\
\text { health and Inten- } \\
\text { sive Care Unit }\end{array}$ & 21 years & F & Diabetic & Cont. \\
\hline 6 & Public & Family Health & 4 years & F & Walking & F & 158 & East \\
\hline 7 & Public & None & 4 years & F & $\begin{array}{c}\text { Family } \\
\text { Planning }\end{array}$ & G & 102 & North \\
\hline 8 & Public & $\begin{array}{c}\text { Family Health and } \\
\text { Public Health }\end{array}$ & $\begin{array}{c}3 \text { year and } \\
\text { months }\end{array}$ & F & Diabetic & H & 181 & Cont. \\
\hline 9 & Public & None & 3 years & F & Smoking & I & 171 & Center \\
\hline 10 & Public & Family Health & 4 years & F & $\begin{array}{c}\text { Pregnant } \\
\text { woman }\end{array}$ & J & 93 & East \\
\hline
\end{tabular}

*Continent

The pre-analysis consisted of the selection of the documents to be analyzed, thus, firstly, the transcription of the recorded interviews, readings and re-readings of the collected material and organization of the data were carried out. The transcripts were stored in ten folder files, organized by the name of the specific group. These documents included the statements of the interviewed participants and the record of the duration, time and place of the interview.

This collection in the field of inquiry established the first classification of the data. The information was organized based on the aims that guided the study, which sought to establish an approximation with the meanings revealed in the statements of the subjects. ${ }^{6}$

The exploration of the transcribed material occurred, with thorough reading in order to capture the main ideas of the theme. The final step was the categorization. The grouping of the data and categorization were performed together in order to impose a certain organization on the statements to give greater credibility to the analysis process.

In relation to the health promotion actions developed by the nurses in the PHC groups, five categories emerged: Nursing education and development of the health promotion group; Duties of the nurse in the group; Methodology of the group; Issue included in the groups, and Results of the group.
Results were discussed considering the framework of health promotion related to PHC.

The study was only carried out after the authorization from the Florianopolis Municipal Health Department and approval of the project by the Research Ethics Committee of the Federal University of Santa Catarina under Authorization No. 46682 FR.476682. In accordance with Resolution No. $466 / 12$, of the National Health Council, the ethical principles of research involving human subjects were respected, as well as the principles of the Code of Professional Nursing Ethics. To maintain the confidentiality of the participants, they were given codes. Numbers were given to the nurses and letters to the Health Units.

\section{RESULTS AND DISCUSSION}

In the first stage of describing the health education groups that were performed in the PHC, a total of 1,363 collective services were found in the municipality of Florianópolis-SC. the following PHC care groups were described in the RAAC: chronic diseases, drugs, health education, supervised oral hygiene, family planning, prenatal care, training, nutrition counseling, epidemiological examination, depression, anxiety, smoking, therapy, sexuality/ STI, childcare, breastfeeding and others. ${ }^{7}$ 
Many care groups were not specified in the RAAC, with the following being those that appear: hypertension and diabetes, older adults, women's integrated health, physical disability, physical injuries, community, child, child capital program, family, adolescent, pregnant women of the $1^{\text {st }}$ trimester, pregnant women of the $2^{\text {nd }}$ trimester, pregnant women of the $3^{\text {rd }}$ trimester, child of the food social program, patient of the cancer prevention program, Worker groups. The collective services described in the RAAC also covered groups for the health professionals, such as training. Intersectoral collective services and the supervised oral hygiene group were involved, which were conducted in schools, not specifically for users of the PHC Units. ${ }^{7}$

The number of collective services coordinated by the teams of the Núcleo de Apoio à Saúde da Família (Family Health Support Center - NASF): could be observed 562 monthly meetings in relation to the 1,363 total health education activities carried out by the teams working in PHC. The teams of the NASF act as a support for the needs of the FHS, not as a substitute for the service. The number of NASF actions seems high, which is why it is assumed that the Units require more time of the FHS for preventive care and curative consultations, lacking space for collective services.

Regarding the description of Health Education actions, there were a total of 247 monthly collective services. This was the second highest number of collective services. These data are consistent with the National Policy for Health Promotion (PNPS), which states that health promotion actions are aligned with the development strategy of personal skills, which is being carried out through educational practices in the PHC groups. For the development of health promotion it is essential to intervene in problems, such as the difficulty of access to education, among others. The PNPS also states that public action should go beyond the idea of healing and rehabilitation. Thus, it is perceived that specific actions, focused on health promotion through information and health education, are being performed by the Network of collective services in the Health Unit. ${ }^{2}$

The selected groups are described in Table 2 , according to their organization of the collective services in the Health Units. The nurses also pointed out that the time and the period of the meetings could change according to the requirement of the Unit or change of professional.

Table 2 - Organization of the groups in the Health Units of Florianópolis, SC, Brazil, 2012

\begin{tabular}{|c|c|c|c|c|c|}
\hline $\begin{array}{l}\text { Health } \\
\text { unit }\end{array}$ & Group & $\begin{array}{l}\text { Meeting } \\
\text { schedule }\end{array}$ & Average time & $\begin{array}{c}\text { Time of the } \\
\text { meeting }\end{array}$ & Report \\
\hline A & Diabetic & Biweekly & $2 \mathrm{hrs}$ and $30 \mathrm{~min}$ & $14: 00$ & Monitoring and Collective Services \\
\hline B & Time to eat & Biweekly & $40 \mathrm{~min}$ & $13: 30$ & Time to Eat Program \\
\hline $\mathrm{C}$ & Time to eat & Biweekly & $2 \mathrm{hrs}$ & 08:30 & Time to Eat Program \\
\hline $\mathrm{D}$ & Time to eat & Monthly & $40 \mathrm{~min}$ & $13: 30$ & Time to Eat Program \\
\hline $\mathrm{E}$ & Diabetic & Biweekly & $2 \mathrm{hrs}$ & $14: 00$ & Monitoring and Collective Services \\
\hline $\mathrm{F}$ & Walking & Biweekly & $40 \mathrm{~min}$ & 09:00 & Minutes and referrals \\
\hline G & $\begin{array}{c}\text { Family } \\
\text { planning }\end{array}$ & Weekly & $40 \mathrm{~min}$ & $14: 00$ & Minutes and referrals \\
\hline $\mathrm{H}$ & Diabetic & Monthly & $1 \mathrm{hrs}$ and $30 \mathrm{~min}$ & $14: 00$ & Monitoring and Collective Services \\
\hline I & Smoking & Monthly & $1 \mathrm{~h}$ & $14: 00$ & Protocol of the Ministry of Health \\
\hline $\mathrm{J}$ & $\begin{array}{l}\text { Pregnant } \\
\text { woman }\end{array}$ & Weekly & $1 \mathrm{~h}$ & 08:00 & Minutes and referrals \\
\hline
\end{tabular}

Training of the nurse and development of the health promotion group

Regarding the professional training, nine out of ten nurses said they received no specific training from the Municipal Health Department to initiate and conduct the groups of PHC collective services. The interviews indicated that the formation of groups emerged from their own experience and from the knowledge of the Nursing Undergraduate Course: [...] I received specific training through the specialization, but nothing focused on Health Promotion (Nurse. 7). 
Nurse 8 highlighted that the smoking group differed from the others, because they receive guidance through a protocol provided by the Ministry of Health, with all the steps of the activities that must be performed.

Although the participants had been prepared at some point in their professional training to carry out group activities, the literature states that the academic background of the majority of health workers is linked to the clinical area. This training hinders the practice of the nurses in PHC. Despite advances in the practical field, the management of the process of their work encompasses meeting the health needs of the population, as well as integrating the care when there is more than one problem. Dealing with this context implies providing multidisciplinary guidance that positively influences the responses of people to their health problems, and for this, committed team work is necessary for the organization of common care. ${ }^{8}$

Regarding the specific issue of professional training, the ease of composition of these groups is evident, however, it is often difficult to maintain them, due to the demand for consultations and outpatient care in the Unit, as well as the reduced number of workers. The Primary Care notebook states that health promotion is one of the organization strategies of the management and of the health practices, which are actions that occur both in the clinic and in the realization and/or performance of participatory groups regarding their specific needs, or in the comunidade. ${ }^{9}$

In the context of $\mathrm{PHC}$, the group is a democratic meeting, where all the participants share experiences, prioritizing dialogue. According to one study, ${ }^{10}$ nurses were the main mediators between all professionals in the group activities, which led to the recognition of the work done by them, because they promoted different activities that allowed breaking with a traditional view of educational activities in health.

\section{Duties of the nurse in the group}

The study found that the educational activities started to require a practice from the professionals that was able to favor the participation of the population, as a way to face difficulties. The actions performed in the collective services are organized into groups for specific purposes, according to the structure and organization of the professionals with the support of the participants. The Walking Group stands out, in which nurses portray the educational activities in the context of health promotion, aimed at improving the quality of life, exchanging experiences and constructing bonds.

It is noteworthy, however, that the formation of groups, is often deactivated due to the poor adherence of the participants, the lack of professionals or the requirements of the team with activities such as home visits and consultations. Despite efforts to include health promotion in the quotidian of the professionals, a focus on curative requirements and preventive activities still prevails. For an effective change, health education practices must be present in the construction of the collective will, of the incitement to participate in the production of new subjectivities in the people, in relation to their health, to the disease, to the institutions, to what until then showed itself as established. ${ }^{11}$

The focus of the practical activities of nurses is still very much linked to chronic disease, such as the Diabetes Group, however, the effort to work with the individual, family and community to construct healthy habits was observed. It is understood that the activities performed are intertwined with health education, although a traditional approach prevails, focused on individuals and their pathologies. It is important to highlight the statement that refers to the health promotion characteristics of the groups that they coordinated: [...] in the walking group you do not need any disease to participate, it is an open group, I think this is more characteristic of promotion, the pregnant woman group also, as they do not have any problem, it works with the question of promotion, care for the baby [...] (Nurse 7).

Advances of the heterogeneous groups were perceived, the Walking Group, for example, takes into consideration the concept of positive health of the National Health Promotion Policy. ${ }^{2}$

The group can be defined also as an environment of interaction of different people, where participants are allowed to speak, hear, feel, question, reflect and learn to think in order to help overcome the changes, allowing their adaptation of the lifestyle to the health condition. The PHC groups take various forms and dynamics, bringing together people with a common illness, promoting attitudinal changes toward the health care. ${ }^{12}$

Another point that should be highlighted is the formation of the groups linked to the medical consultations, where adherence of the participant is facilitated, such as the Pregnant Woman Group. The dynamics of the groups occurs prior to the scheduling of the medical consultations. Participants arrive early and are encouraged to participate in educational activities, at which time they discuss the 
acceptance of the clinical treatment and behaviors that can prevent health problems. Although there are aspects related to health promotion, the study shows that the predominant concern is to raise awareness of adherence to medical treatment and behaviors that can prevent health problems.

Health educational actions, in the group activities, show that their development is directed toward promoting the health of the individuals, making them more confident in choices of behavior change, and acquainting them with the communication process in the exchange of knowledge. Communication and teamwork allow the work process to become an instrument to produce co-responsibility, resolutivity and autonomy in the clients, for the transformation of the ends into products. ${ }^{13}$

\section{Methodology of the group}

The nurses pointed out that the performance of the groups does not generally follow any specific methodology. They stressed the participatory approach as the main method, however, this depended on the activities selected and professional that carried it out. Furthermore, they stated that the performance of activities is dynamic, with an open space, which does not use approaches in the form of lectures, in order to better meet the needs of the participants in their daily lives.

[...] There are no lectures, it is a wheel of conversations, the methodology we use is to understand the needs of the participants, of their life, of their quotidian (Nurse. 4).

The Smokers Group follows defined protocol standards established by the Ministry of Health, with the steps that should be adopted in its performance. As a specific methodology, the respondents revealed that they participate in training, which takes place annually, promoted by the Municipal Health Department, providing opportunities for qualification to perform the group at the Health Unit.

The interviewees confirmed that traditional methods are still used extensively when conducting the groups. This pedagogical tendency is revealed through a knowledge produced throughout history and passed vertically to the population by the health professional, without many questions or dialogue. On the other hand, nine respondents highlighted using participatory and dialogical methodologies, with user involvement. This approach was highlighted, especially in the activities of walking, cookery, discussion of issues in wheels, using dialogic dynamics and with the participation of different professional, however, there was no emphasis and articulation with the activities of health promotion.

The methodology used in the groups is similar to that of Paulo Freire, which possibly provides new methodological possibilities of action, taking into account the question of traditional practices based on the problematizing/liberating action. This pedagogical proposal exceeds the limits of education, as a social context, and is also understood as a way of reading the world, reflect on this reading, and retell it, transforming it by conscious action. ${ }^{14}$

A desire for gradual change in the adoption of a participatory methodology is perceived, however, in their statements many professionals were discouraged because they perceived that users did not actively participate in the group, not being responsible for their health, and needed to be encouraged to undergo the process of change.

\section{Themes included in the groups}

The immersion of the themes is constructed with the group name itself. These are specific, such as, diabetes, hypertension, and directed toward care for the disease. The themes were selected from the daily reality of the unit. The participation and performance of other professionals should be noted, such as the physical educator, for promoting specific themes, such as physical activity. The participants highlighted that they sought themes without the focus on the disease, using the wheel of conversation to extract the issues from the life experiences. Varied subjects are included in the Walking Group, as it is a multidisciplinary, heterogeneous group, which is not focused on the pathology or on chronic diseases.

In the Smokers Group, which follows a proto$\mathrm{col}$, the subjects are specific to empower the individuals so that they can stop smoking in four months. In relation to the chronic disease groups, such as diabetes and hypertension, the subjects are focused on the pathophysiology. All include physical activity and nutrition. One respondent pointed out that they work with stress and playful activities to confront disease versus feeling. Another reported covering the main difficulties with the psychologist of the NASF.

In the Pregnant Woman Group, in which the nurses interviewed reported that they emphasize health promotion, they approach the issues of women's health, vaccination, sleep, oral health, hygiene, stress, feelings, maternity rights, body symptoms and changes, perineum strengthening, physiological changes, birth, breastfeeding, and pediatric care. Regarding the Time to Eat Group, 
food issues, pathophysiology, the Bolsa Família social program and vaccination campaigns are addressed. The Family Planning Group specifically covers contraceptive methods. A substantial demand for this group was found, with the participation of men to perform vasectomy, which often contributes to avoiding unwanted pregnancies.

[...] You must repeat the topics so that the participants do not forget them and they are not always the same participants [...] (Nurse 6).

In the statements, it was observed that the issues are chosen by the participants, or by the professional if he/she notes something important to discuss. Depending on the theme, a professional of the NASF can take charge. It is emphasized that the educational health practices should strengthen the participation of all, so that the individuals recognize and differentiate themselves from the others, transforming and assisting in the change, aimed at autonomy, citizenship and interdisciplinarity. ${ }^{15}$

\section{Results of the group}

The results achieved included, benefits with self-care, interest of the participants, improvement in quality of life with changes in habits, trust in the professionals, reduction of unwanted pregnancies, increase in the number of consultations, and the success of new mothers breastfeeding. Regarding health promotion information, only one professional was confused when responding to the question, due to relating the actions with curative activities and medical work. The results also showed that the health care professionals know the importance of promoting health, however, do not take a careful look at these actions. They perceived health promotion actions to be strongly linked to the Walking Group. The activities of this group show that its formation is not necessarily linked to the disease, i.e., in it food education and taking advantage of the environment of the neighborhood are covered, to deal with diverse issues.

The importance of the basic food hamper provided by the Time to Eat Group is emphasized, aiming to help with weight gain for children that need this. It was perceived that even when the results had been achieved, the participants continued to take part in the program.

[...] The results are good, but, it is still a paternalistic policy [...] (Nurse 3).

[...] I wish it had 20\% of the work time to promote health and $20 \%$ for the curative part; today is not viable, there is little time to carry out promotional activities [...] (Nurse 4).
In the Paternalistic Policy, highlighted by the respondents in relation to the Time to Eat Group, it can be seen that this policy is consistent with the autonomy of the individual and that can translate not only a stigma to the beneficiary, but can mainly promote citizenship that can be called passive. ${ }^{16}$

Thus, this must be active and also responsible, having the ability to choose what is best for the health. The health services and other sectors must provide conditions, tools and subsidies for the individuals to be strengthened, so they can return as soon as possible to the social life. Thus, the distribution of the basic food hamper should be stopped when the child reaches a healthy weight. Programs cannot be permanent, but should be carried out temporarily; otherwise, it alienates and debases the dignity of the citizen. ${ }^{17}$

On the other hand, the inclusion of the Bolsa Família and other social programs provided access and improved the income of a large portion of the population. These actions can be understood as intersectoral strategies that comprise the fields of health promotion, and aim to combat the misery and poverty of a large number of people in the country, in addition to intervening in the social determinants of health.

The relationship between health education and the framework of Paulo Freire is much more than a relationship, it is the essence of the process. It is justified by the form of the theoretical approach to the process of construction and reconstruction of the reality. The horizontal dialogue enables the option of choice and promotes individual empowerment, contributing to the collective. This aspect correlates the recognition that health, as it becomes identified not as the absence of disease, but as quality of life, demands a set of actions that go beyond the area of health. ${ }^{18}$

\section{FINAL CONSIDERATIONS}

It was found that health promotion actions were presented as a broad concept and that intersectoral, individual and collective commitment is necessary for their implementation in the practice, since this not only depends on the health sector. Regarding health education activities, many were described as group discussions, exchange of experiences, professional guidance. The nurses highlighted that the aim of the group is to improve the quality of life of the individual, family and community. A strong understanding of these professionals was found regarding how to apply health promotion in 
the activities, focusing on quality of life, not the disease, even though the groups were still centered on the pathology, such as hypertension and diabetes. In addition, the comprehension of the participants was noted in the inclusion of actions, such as physical activities, seeking quality of life.

It was also noticed that in some groups, the actions were related to the diagnosis and management of diseases, devaluing the health promotion practices. To ensure the promotion of health it is relevant to perform these groups in the units, with their continuity to improve the quality of life, encouraging the individuals to take care of themselves, and the transformation of the health care model centered on the disease. The PHC groups fulfill one of the strategies of the 1986 Ottawa Charter, that of personal skills, in which health promotion supports personal and social development through the dissemination of information, health education and enhancement of vital skills. Although a health model with a focus on disease still prevails, change can be seen in the workplace, which focuses on individuals in their entirety and universality, seeking to take into consideration the family and the community. With this study, it was possible to analyze the concepts of promotion for specific questions on the subject, and awaken the investigation of new paths, such as knowing how the participants felt about the performance of the groups.

Knowing the health promotion actions developed by nurses in the PHC collective services, in Florianópolis, also allowed the identification of the training of nurses for the group, their duties, the methodology used and the themes included. It was noticed that the nurses were aware of their importance and that of the health promotion practices, as well as good understanding.

It is understood that there were efforts at the local level of the units that allowed advances in the transformation of the educational practices in the groups, preventing the actions from being reduced to an imposed education and emphasizing the participatory methodology. The reorientation of the traditional practices requires investment in infrastructure, in human resources, and in research aimed at promotion.

It is understood that a limitation of this study was the fact that specific methodologies were not identified or evaluated in the work process, not being able to perform a deeper study into the conduct of these groups, which is one of the main strategies for the operation of the PHC Network. Also, there was no consultation of the users. Recommenda- tions for future studies include the evaluation of the health education with the users of the FHS and the systematic inclusion of dialogic educational practices, for which the liberating education of Paulo Freire is suggested, and group practices, which allow users to actively seek their health. Furthermore, there is a need to construct evaluative methodologies for the verification of the limits and potentials of the activities carried out in the PHC groups.

\section{REFERENCES}

1. Chung YL, Hee S, Kim YH, Ahn ISK, Yoon HC. Development of a community health promotion center based on the World Health Organization's Ottawa Charter health promotion strategies. Jpn J Nurs Sci. 2009 Dec; 6(2):83-90.

2. Ministério da Saúde (BR). Portaria n. 2.446, de 11 de novembro de 2014: redefine a Política Nacional de Promoção da Saúde (PNPS). [cited 2016 Jul 12]. Available from: http://bvsms.saude.gov.br/bvs/ saudelegis/gm/2014/prt2446_11_11_2014.html

3. Almeida ER, Moutinho CB, Leite MTS. The practice of the health education in the perception of the diabetic and hypertensive users. Saúde Debate [Internet]. 2014 [cited 2015 Apr 12]; 38(1):328-33. Available from: http:/ / www.scielo.br/scielo.php?pid=S0103$11042014000200328 \&$ script=sci_abstract

4. Maffacciolli R, Lopes MJM. Os grupos na atenção básica de saúde de Porto Alegre: usos e modos de intervenção terapêutica. Ciênc Saúde Coletiva [Internet]. 2011 [cited 2015 Apr 12]; 16(1):973-82. Available from: http:/ / www.scielo.br/scielo.php? script $=$ sci $_{-}$ arttext\&pid=S1413-81232011000700029

5. Alves LH de S, Boehs A E, Heidemann ITSB. Family health strategy professionals and users' perception on health promotion groups. Texto Contexto Enferm [Internet]. 2012 [cited 2015 Apr 12]; 21(2):401-8. Available from: http://www. scielo.br $/$ scielo.php?script $=$ sci_arttext\&pid $=$ S010407072012000200019\&lng=en\&nrm=iso\&tlng=en

6. Minayo MCS. O desafio do conhecimento: pesquisa qualitativa em saúde. São Paulo(SP): Hucitec; 2010.

7. Prefeitura Municipal de Florianópolis (BR). Rede docente assistencial: histórico [Internet]. Florianópolis (SC): PMF; 2011[cited 2011 Jun 3]. Available from: www.pmf.sc.gov.br

8. Moutinho CB, Almeida ER, Leite MTS, Vieira MA. Dificuldades, desafios e superações sobre educação de enfermeiros de saúde da família. Trab Educ Saúde. 2014. 12 (2):253-72.

9. Ministério da Saúde (BR). Anexo um da Política Nacional de Promoção da Saúde. Biblioteca Virtual em Saúde [Internet]. 2006 [cited 2015 Sep 6]. Available from: http:/ / bvsms.saude.gov.br/bvs/publicacoes/ portaria687_2006_anexo1.pdf 
10. Silva FM, Budo M LD, Girardon-Perlini NMO, Garcia RP, Sehnem GD, Silva DC. Contribuições de grupos de educação em saúde para o saber de pessoas com hipertensão. Rev Bras Enferm. 2014; 67(3):347-53.

11. Jackson SF,Birn AE, Fawcett SB, Poland B, Schultz J A. Synergy for health equity: integrating health promotion and social determinants of health approaches in and beyond the Americas. Rev Panam Salud Publica. 2013; 34(6):473-80.

12. Silveira LMC, Ribeiro VMB. Grupo de adesão ao tratamento: espaço de "ensinarem" para profissionais de saúde e pacientes. São Paulo (SP): Interface: Comunic, Saúde, Educ. 2005; 9(16):91-104.

13. Cardoso LS, Cezar-Vaz MR, Silva MRS, Costa VZ. Finalidade do processo comunicacional das atividades em grupo na Estratégia Saúde da Família. Rev LatinoAm Enfermagem [Internet]. 2011 [cited 2015 Mar 25]; 19(2): [07 telas]. Available from: http://www.scielo. $\mathrm{br} / \mathrm{pdf} / \mathrm{rlae} / \mathrm{v} 19 \mathrm{n} 2 / \mathrm{pt} \_23 . \mathrm{pdf}$

14. Heidemann ITSB, Wosny A, Boehs A. Promoção da Saúde na Atenção Básica: estudo baseado no método de Paulo Freire. Ciênc Saúde Coletiva. 2014; 19(8):3553-9.

15. Acioli SA. Prática educativa como expressão do cuidado em saúde pública. Rev Bras Enferm [Internet]. 2008 [cited 2015 Mar 25]; 61(1):117-121. Available from: http://dx.doi.org/10.1590/S0034-71672008000100019

16. Rodrigues MP, Lima KC, Roncalli AG. A representação social do cuidado no programa saúde da família na cidade de Natal. Ciênc Saúde Coletiva [Internet]. 2008 [cited 2015 Mar 25]; (13) 1:71-82. Available from: http://dx.doi.org/10.1590/S1413-81232008000100012

17. Marques A. Dimensões da autonomia: o programa bolsa-família no discurso midiático e na fala das beneficiárias. Contra campo [Internet]. 2006 [cited 2015 Mar 25]; Available from: http://www.uff. br/contracampo/index.php/revista/article/ viewFile/517/359

18. Ferreira N, Leite J, Kind L. Práticas grupais como dispositivo na promoção da saúde. Physis: Rev Saúde Coletiva. 2010; 20(4):1119-42. 